\title{
Eastern Democratic Republic of the Congo on the way to peace? War remembrances, post conflict discourse construction: a discursive analysis of Djungu-Simba's novellas
}

\author{
Felix U. Kaputu \\ Department of Languages and Cultures, Ghent University, Belgium
}

\begin{abstract}
Throughout the history of the Democratic Republic of the Congo, various writings - literary, sociological, and political - retrace the challenges that have faced the nation: colonialism, access to independence, postcolonial failures, wars, dictatorships and female exploitation. Some historians, sociologists, literary critics and journalists touted the successes of colonial times and the first Republic, especially those who worked for these governments. Other essential voices remained silent, in order to avoid dictatorial repression and censure, especially under President Mobutu. With the arrival of Laurent Kabila, freedom of speech brought forth discourse that slowly deteriorated into insincere rhetoric and, finally, utter silence. In Les Terrassiers de Bukavu: Nouvelles, Charles Djungu-Simba, the editor of several Bukavu Congolese novella writers, predicts that the sociopolitical discourse put forth in such narratives will lead to chaos followed by further repression that will continue the cycle presented all along these metanarratives unless oppression is radically addressed from the grassroots.
\end{abstract}

Key words: Bukavu, violence discourse, war, apocalyptic myth, UN Forces, Democratic Republic of the Congo, novellas

\section{Introduction}

Violence and armed conflict in the eastern Congo has, for the past seventeen years, endangered people's lives, scattered communities, pitted neighbors and neighboring countries against each other, and caused poverty and chaos. These ills have moved writer Charles Djungu-Simba, a native of the area, to weave stories by a range of writers, constructing a semiotic discourse that is situated at the border of memory, creation and destruction. This discursive analysis looks at narratives presented in Les Terrassiers de Bukavu: Nouvelles for a post-conflict discourse construction. These narratives utilize the same literary and mythological dimensions as oral narratives with regard to production setting, theme and sound repetition, parallelism, digression, imagery, symbolism and their am- 
plification. However, they tend to depict a higher level of violence and negative impact in the Democratic Republic of the Congo, including malfunction, deliquescence and total chaos. Charles Djungu-Simba K. (2009) puts together novellas written by a number of generally unknown writers who provide first hand testimonies of wars and conflicts in the eastern Congo. He also includes his own contribution, a novella entitled "Postscriptum". A native of South Kivu in the Democratic Republic of Congo, his long career includes work as journalist, political advisor, critic and researcher. He has participated in many literary forums, and is known for his novels, novellas, short stories and cultural programs. He received his PhD from Antwerp University, and works there as researcher in Francophone literature.

This paper addresses the ways in which Djunga-Simba's book contributes to understanding the cycles of violence and the beginnings of new political eras. Specifically, this paper analyzes the ability of the book to articulate a socio-political discourse addressed to Bukavu people, Congolese, and the world, in terms of the current state of the country and possible steps that could lead to healing the psychological wounds of war and the restoration of the country's wellbeing.

\section{Literary texts that reflect social phenomena}

Waugh (I992) states that fiction can serve as a medium to explore apocalyptic narratives, a sense of crisis in a relationship with postmodernism. As such, fiction becomes and stands for a cultural artifact that presents the concerns of the age, thus exemplifying Rancière's (2004) understanding of literature as reflecting real sociological issues. Many literary critics contend that literary texts using various techniques may, in fact, be the most useful tool for depicting and studying social changes (Foster, I947; Booth I967, 1983; Yasui, I982; Walsh, 2007, Cuddon 1998; Abrams and Harphan, I999; Rancière, 2004). Regarding Djungu-Simba's work, these critics concur on the writer's capacity to depict and manage current social phenomena.

The texts contained in Les Terrassiers de Bukauu provide readers with several opportunities to move both in terms of fiction and reality within particular narratives, and thus apply Jacques Rancière's (2004) understanding of fiction to socio-political polemics on the eastern Democratic of the Congo in general, and Bukavu in particular. By combining the oral narratives' communication strategies and the novella as literary genre Djungu-Simba and the other novella writers successfully provide readers with a strongly documented file of the last decades in a war-torn and decadent eastern Democratic Republic of the Congo, particularly in the city of Bukavu. Their narratives are based on memories of violence and conflict that the writers have witnessed first hand or know of through accounts from close relatives. The eastern region of the Democratic Republic of the Congo has indeed been at war since 1997, and is currently known as the world capital of rape (Carly Brown 20I2: p. 2, C. I). Many waves of people moved from there as IDPs (Internally Displaced People). Many others have found refuge in foreign countries.

In Djungu-Simba's collection of novellas, many storylines clearly reflect current events in the Congo. Djungu-Simba obviously manages to involve the reader either by 
keeping him far from the situation depicted, or close with characters with whom feelings are shared. Freeman and Harvey (I967), Cuddon (I998), Abrams and Harphan (I999), Yasui (I982), and Walsh (2007) strongly side with Immanuel Kant's Critique of Judgment (I790) and interpret the concept of distance in terms of contemplation, aesthetic experience, and psychological sharing with the text.

In the first novella, "Et le Ciel S'assombrit", ["And the Sky Darkens"], interactions between Waku, Bonané her husband, Jonathan their son, their friends Tchim and Willo, and the young student Anastase Sengiunva, revolve around the wars, killings, and hatred now going on in the eastern Congo. This socially anchored presentation is duplicated and amplified in the other narratives, as well. While strictly political texts may strike the reader's attention through a mixture of clear ideological options, simple demagogueries, sophisticated rhetoric periods, and popular inflaming orations, the literary narratives selected in this book instead move from general aesthetic motifs to personal and community interpretations. This is carried out with cautious steps and a clear sense of balance that reflect fiction and non-fiction literature in creative writing (Wellek and Warren:I956). These interpretations turn around selected indicators of human movements, conditions, behaviors, and reactions illustrating the quick degradation of life through successively more desolate images and scenes.

Broader social issues are also evident in the book. From the first novella, the reader discovers how the lack of food has an impact on the African legendary tradition of sharing. Bonané and Walu's family have closed all doors even though, as Tchim points out, the outside temperature is around thirty-nine degrees Celsius, (p. 32). This family seems to understand and to justify why their son, Jonathan, provokes and bullies his classmate Anastase Sengiyunva because of his facies. Anastase Sengiyunva is identified with those who brought war to eastern Congo, i.e., Rwandans and Burundians, even though he is not one of them and is only a child. It is again around family talk, through an epistolary correspondence, that Clementine is informed of the machete culture; killing "the other" who is perceived as a different being, who steals or cheats, or who spreads death via irresponsible behavior and HIV-AIDS (p. 55).

The third novella focuses on the presence of evil which dwells within the human condition. The hospital nurse shows that he is all-evil (p. 77), preferring money to helping the wounded and suffering people. The same evil is depicted in the fourth novella "De La Résistance à la Libération", ["From Resistance to Liberation"], in which Timon betrays his friends Passy, Harry and Nando, who wish to raise local resistance against an absurd occupation (pp. 8I-82). The fifth novella "Les coulisses d'une Ville Oubliée", ["The Corridors of a Forgotten City"] shows a revolution of sorts from the creator. Bukavu people cannot pretend to deserve God's mercy if they do not have the same mercy within their families and neighborhood. Many of them have also contributed to the maintenance of omnipresent evil. "Phtiriase sur Bukauu", ["Phthiriasis on Bukavu"] shows how even human suffering and dehumanization are changed in an opportunity to obtain money especially through NGOs (pp. II9-I23). The seventh text "Post-Scriptum" shows how evil is omnipresent through the example of the couple Cyprien and Sengera. The man lends his wife to a UN agent for money. 
Through the succession of events in Les Terrassiers de Bukavu: Nouvelles the reader may see a kind of traditional fable, a generalized tale that emerges from the presentation of a cycle of evil from beginning to end. As such, each novella can be viewed as a section of one narrative. Together, these novellas reflect oral tradition performances that lasted several nights, and needed the public for different aesthetic contributions, and mnemotechnical strategies that helped performers to quickly remember the coherent succession of narrative sequences.

The narratives in Les Terrassiers de Bukauu: Nouvelles present increasingly chaotic scenes, presenting the pattern of an apocalyptic myth in which chaos precedes novelty and recreation, and which leaves open the possibility of the re-construction of a better country through an apocalyptic myth pattern. In this vein, Rahman (2009) goes a step further as he looks at the capacity of apocalyptic narratives to situate a period of recuperation following a period of immeasurable violence that is particularly directed at the "other". He contends that this kind of narrative is self-perpetrating, self-fulfilling and itself remains one of the sources of the endless internal violence. Leonard and McClure (2004) and Rahman (2009) contend that political issues often take on religious issues and the other, a situation in which the other, being held responsible for all ills, is dehumanized. At the same time, there is in the background a space that offers a chance of redemption to even the worst criminals. Such apocalyptic cycles are reflected in the frame of Les Terrassiers de Bukavu: Nouvelles, with the stories and the sequence in which they are presented, leaving the hope that, after many years of death and desolation, recovery and reconstruction will unfold in the Democratic Republic of the Congo.

\section{A long tradition of discourse on the Democratic Republic of the Congo}

This chapter depicts the long-standing tradition of political discourse in the Democratic Republic of the Congo. While the primary vehicle of the apocalyptic myth story line that links the novellas in Djungu-Simba's selection, is fiction, the narratives also reflect a long tradition of political discourse based on key political actors' demagogies, that is conveyed in different writings (fiction and non-fiction). Conrad and Rubango, later documented in this chapter, are but an illustration of the ways in which these political discourses may be conveyed to the public. Djungu-Simba contributes to this long tradition and finds a specific way of depicting those political discourses that have led to the chaos both in Bukavu, and more generally in the Democratic Republic of Congo. The reader who is aware of the country's political history since independence, will have no difficulty noticing the general insecurity that has prevailed in many places during this period and the key role that political leaders have played in that general failure. Increasingly, screened popular theater, music, popular comedies, and even funeral songs contribute to the exposure the ineffectual discourse of politicians who are incapable of bringing about peace and welfare. Strategies used to reveal these discourses vary from theaterical reproduction (words and characters building up politicians' profiles, and incompetences), to more elaborate creative writing, including the novellas that Djungu-Simba has selected. 
Writing strategies on the Congo have traditionally involved the works of individual writers subjectively interpreting different socio-political events. Djungu-Simba inaugurates a new trend that mixes local testimonies collected from oral sources or written (obviously translated) sources and written communication techniques, mostly by unknown writers' presentations of major social issues in order to convey a socio-political discourse through a recurrent and incessant semiotic chaos. It is worth mentioning that a particularity of the orality here exploited moves from old traditions, where the storyteller, a bard, griot, or reciter was the entertainer, to home and neighbors' talks on their fears, suspicions, and virtual hopes, all rendered under tense short narratives and calling for a range of emotionalreactions.

In collecting novellas in Les Terrassiers de Bukavu: Nouvelles, Djungu-Simba presents a compendium of current events. Like the long tradition of oral story-telling or the presentation of life in novels such as Joseph Conrad's Heart of Darkness, Djungu-Simba's collection of brief narratives, which center around the recurring theme of war and depiction of violence and human abuses in the Congo, may ultimately and hopefully contribute to positive social change. Unfortunately, based on the evidence of history, such a positive outcome ultimately may only be realized after decades of destruction and chaos through oppressive dictatorship have been inflicted on the country.

Early writings on the Democratic Republic of the Congo, such as Heart of Darkness, developed many rhetorical discourses on the discovery of an uncivilized continent, using mythological, unrealistic, even racist terms to depict Africans. Very quickly, however, writers' paralipses took on a new direction due to, on the one hand, absolute censure and lack of freedom, and on the other, the weakness of national education. This new direction expounded on King Leopold II's exploitation of the Congo, first as his own personal property, and later as a colony of the kingdom of Belgium. These first discourses tended to attack colonialism, and continued their denunciations until the Democratic Republic of the Congo became an independent country. Throughout this process, political critics received more and more support from Belgian polities clearly opposed to the colonization project.

Belgium, however, could not derogate to the international pressure, it granted Congo its independence in relatively acceptable official lines shaken by Prime Minister Lumumba's unscheduled speech quickly followed by his still legally disputed internationally motivated and planned death (Ludo de Witte, 2002). The independence was indeed granted under much international pressure as the international community had already backed up the independence of a number of African countries. At the same time, Lumumba's uncontrollable changes and hatred of the West were a big challenge for the international community, and the building of anew nation.

A close look at Lumumba's life reveals a history of personal and identity changes that inevitably lead to his leadership. Two of Rubango's texts (I999, 200I) elaborate on Lumumba's political discourse and depict the evolution of his controversial personality, including his name change from "Isaïe" to Patrice. Lumumba quickly replaces his birth names Tasumbu Towasa with the rather more popular name Lumumba, which means "a 
moving crowd." To clearly demarcate himself from his village and people, he adopts the name of a leader often associated with whiteness or white leaders without pointing out his intention to be the same kind of leader. He takes the name of Osungu or white man (Rubango, 2000, p. 174). His other name, Emery, is said to be an imitation of a Belgian name - Hemerijckx - he knew in his childhood or one of the first évolués, Emery Pene Senga, from his village (Rubango, 2000, p. 175). These name changes metaphorically represent Lumumba's personal attitude towards politics and power and the development of this leader can be understood through oral narrative techniques that depict his long transformational process from a community member to the embodiment of a cultural hero (Biebuyck and Mateene: I989). Undoubtedly, Lumumba's lifestyle, also a topic of literary productions and the formulation of political discourses, preludes and duplicates his dual political discourse that often seeks to please the dominant power while hiding his personal convictions. During his political life, he gives speeches that laud and the colonialists' work. Even after his incendiary speech at the independence ceremony, he congratulates Belgians on their civilized bearing and humanitarian work. One can only wonder whether this contradictory attitude is a discursive strategy to mitigate the pressure and danger he quickly experiences after being labeled a communist. Lumumba's style is here stressed in a bid to underline how Congolese political leaders are part of a long tradition that does not necessarily adhere to the needs of the people, but rather reflects egotistical views that are made concrete at the expense of their countrymen's welfare.

Whatever the reasons, during the post-independence period, Congolese politicians (and intellectuals) adopt very similar strategies in their socio-political analyses. Their discourses aim at openly pleasing political authority, whereas the truth is found in private talks held behind "curtains", "radio-trottoir" (side-walk radio), or very far from home in the Diaspora. In I975 during President Mobutu's regime, a so-called Institute emerged, the "Institut Makanda Kabobi", which was a national school of ideology training demagogues. The aim of the organization was to promulgate a national discourse on power and the "everlasting, mythical, presidential hero, and founder of the nation", in effect the official presentation of the country leader. Under a total lack of freedom, the national political discourse follows Lumumba's self-flattering pattern in presenting Mobutu as an idol and an icon. At the same time, especially in countries far from home, every opportunity is taken to describe Mobutu's dictatorship in more objective terms. Nguz Karly I Bond (I938-2003) is a very good example of that kind of Congolese Politician. Educated in Belgium, he went back to work in the Congo and led a very tumultuous political life, spending much time in exile. Put in prison, he was presented as the political opponent to President Mobutu. However, it is only when he went to Belgium on an official visit and chose exile that he was able to communicate to the world details of President Mobutu's dictatorship.

Consequently, a few years after, President Mobutu's fall coincided with a virtual return to freedom of speech feted through many newspapers and magazines. Suddenly, the Congolese media found much pleasure in changing any acronym or official name in order to poke fun at the once feared political authorities and institutions. At the same 
time, other more academic writings used of major national events as a pretext to produce critically adapted texts (Rubango, 2009, pp. 676-678). Such writings cover all aspects of social life, from local students' upraising or massacre to the invasion wars from the East, and highlight the resulting poverty that obviates the claimed revolutionary benefits.

\section{Political discourse strategy changes and the current Rwanda crisis}

In Les Terrassiers de Bukauu: Nouvelles, Charles Djungu-Simba offers a strategy the lies at the crossroads between reality and fiction. By using history, fantasy, and above all community memory in locally well-documented narratives, his work plays on readers' subjectivities. Without overstressing oral literature details, Finnegan (I970, pp. 4-I2), Sekoni (I990, pp. I39-I4I), Okpewho (I992, pp. 30-4I), Ngandu (I984, pp. I6-I7) suggest that Djungu-Simba and the other novella writers seem to utilize visual and sound resources and develop narratives that captivate the audience, transfer experience, and together create a work of art. As such, Djungu-Simba is comparable to a griot leader, the master and a leader of an evening's entertainment, making possible the passage from factual events to the world of dreams moving the audience to a realm where the cultural hero's a-temporal grandeur is in full control. He manouvers the audience into a co-creation process of the "illo tempore" with the public through a continuum that reveals and teaches (Biebuyck \& Mateene, I989: I-48). Unlike the traditional bard whose collections were gathered from hard to identify sources and transmitted from one generation to the other, Djungu-Simba's contemporary novellas collected from local writers directly consider the first and the second audiences. Following African oral narrative production strategies, writers "write" their own stories and then listen to the stories of their peers contributing to the general aesthetics and social entertainment where words, music and body steps become one; to construct a common social frame that gives birth to a new meaning, otherwise known as maieutic process. As pointed out earlier, through amplification and circumambulation, and with their capacity to summarize and repeat the main themes, the novella writers standing for storytellers - facilitate the sharing of stories already known by their public, as the eastern Congo violence is largely documented. They still captivate and hold readers' attention (or that of the participating audience) through details that make sure the amplification is well conveyed. Bullying, criminal behaviour, cheating and defrauding, prostitution and HIV-AIDS, shooting innocent people, betrayal, earthquake, confusion and desolation, abuses and dehumanization, as reported in the seven novellas, participate in the loss of human dignity, and in the general suffering that becomes amplified through war violence. Charles Djungu-Simba looks at these male and female writers as wise producers, the first consumers of the narratives, and also as first and second audiences of a product finally presented to a wider audience all around the world. As such they seem to follow the narrative production mode that O.R. Dathorne (I976) sees as including an audience that is already aware of social situations, and gives contributions at different performance levels. Blair (I976) insists on the capacity of oral literature to involve the audience through choruses and repetitions, a co-creation process that offers much that through the griot contributes to communal aesthetics and comprehension. 
In this book, the reader witnesses novelty as the concept "griot" changes into a literary device for both "mythbreaking and mythmaking" - as Charles Djungu-Simba along with Hale (I997), Murphy (200I) and Nzbatsinda (I997) confirm, this is a role change that signals both continuity with and a break from the communication styles of the (griot) past. In addition, Djungu-Simba puts the selected novellas into a coherent order that confirms a general apocalyptic myth and its subsequent chaos. He subtly encourages the reader to become involved in taking up new responsibilities for the rebirth, and by the same token, happily bridging oral traditions in their forms, content and social responsibilities. The African written griot aspirations open to semiosis, metanarratives and twofold stories. Thus, the griot-audience-centered technique supports Guattari's understanding of subjectivities in construction exposed to shared experiences and analyses revealing different sides and details of the same message. And in the same vein, Umberto Eco (I984) provides us with an excellent description for understanding communication processes, message production, code reading and readers' contribution through an open narrative left to their creativity for a natural ending that is different from the chaos the novellas suggest. Communications as noted in the above mentioned examples turn around daily questions and community preoccupations as violence becomes omnipresent. From Jonathan who bullies a classmate in the first novella, a succession of violent activities stand for waves that rise up with different strength and height in all narratives.

Charles Djungu-Simba's collection of novellas Les Terrassiers de Bukavu: Nouvelles stands more as a collective work than the result of a personal presentation. Moreover, the writers of the novellas are not only scholars, but also a sample of the local population with whom for many years they lived through war and violence. As previously indicated, the novellas included in Les Terrassiers de Bukauu: Nouvelle represent different aspects of Bukavu today, a location that also serves as a microcosm of the Democratic Republic of the Congo. The country's multiple facets irremediably emerge and reflect a long chain of event moving to the illo tempore, the continuum of creation in the long past often seen in mythic connotations. Mircea Eliade (I96I, I978, I990, 2004, 2005) whose scholarship turned essentially around myths, ancient religions, shamanism, rituals and socio-cultural contexts, describes how social performers lead the way in socio-religious rituals in ancient and modern times in an attempt to catch up the original "Imago Mundi" at the set of creation where everything is perfect without any kind of corruption. The author groups and links these novellas into segments that build up or create a new kind of Congolese literary and socio-political discourse stimulating a sense of self-respect, progress, solidarity and responsible government. Importantly this amplifies the commitment of early African writers to literature that serves the welfare of their population.

In this vein, Buckley-Zistel (2008) offers an excellent illustration of indicators she uses to show how Rwandans have moved from the 1994 genocide environment towards a national identity. The author describes how national politicians lead their countrymen to look differently at each other, and depicts Rwandan unification around a citizenship principle in a post-conflict perspective that puts an end to cleavages that turn around ethnic interests. Charles Djungu-Simba's selection of novellas focuses on each novella's 
description of the long lasting war that Prunier (2009) describes in terms of continental war. The narratives, taken together through an apocalyptic myth, depicts chaos that coincides with a starting point for a better future in a new environment, a new country with people and neighbors who behave differently. However, the long narrative also resembles the phoenix myth, by insisting on the complete chaos that buries everything, and makes the unknown future seem more threatening.

In fact, in the first novella a long delayed letter arriving from Rwanda bringing bad news to the couple Bonané and Walu (p. 3r), the identification of Rwandans and Ugandans as attackers of Bukavu under the cover of Congolese rebels - Banyamulenge (pp. 3234), build up the main Bukavu victimization pattern repeated with a few variables. This pattern is also found in the second novella "Les Malheurs de Josephine", ["Josephine's Misfortunes"] that shows the beautiful Josephine (p. 5I) as a victim of the socio-political development that leads to her sad HIV-AIDS related death. Unfortunately, she leaves a list of one hundred and fifty six contaminated victims, which means she knew she was contaminating them. The third novella stresses that the proximity of the Democratic Republic of the Congo and Rwanda in the neighborhood is not necessarily a good omen of peaceful coexistence, nor can one assume a small country like Rwanda is militarily weak and passive. Bombs from Rwanda send Doc Ka, his family and many other people wandering in the wild (pp. 7I-72, 74-75). In the fourth novella "De la Résistance à la Libération", ["From Resistance to Liberation"], Passy, Harry and Nando experience how betrayal, mistreatment and killing are not exclusive to Rwanda - they happen in the Congo as well. Their own government unjustly puts them in security cells, and on several occasions attempts to kill them (p. 82). The fourth novella "Les coulisses d'une Ville Oubliée", ["The Corridors of a Forgotten City"] shows how nature seemingly reacts to human actions as not worthy of God's love. On a Sunday, at a church service, a strong earthquake shakes Bukavu three times (p. I05). It leaves houses in ruins, and Bukavu people homeless and wandering aimlessly. The sixth novella, "Phtiriase sur Bukavu", ["Phthiriasis on Bukavu"], delves into the interpersonal mistreatment and injustice found at the grassroots level (pp. II9, I2I, I23). Many people are involved in immoral acts such as collecting money from their family members, neighbors and anonymous others. Increasingly, people are used as a means rather than an end: theft, forgery, unlawful constructions reflect a deep decadence. The seventh novella, added as a post-scriptum, "Rendez-moi ma dignité !", ["Give me back my dignity"] applies the initial pattern within a household context turning a blind eye to bullying, and the sacredness of marriage. Rebel chiefs raped Cyprien Shamavu's wife, Eulalie Sengera Segheta for about one month. Later, Cyprian Shamavu "lends" his wife to a UN liaison officer, Brian Fergusson for money (pp. I46, I49). Sengera Segheta goes for good with the UN officer and Cyprien becomes mad (p. 15I). The original bullying pattern and turning away from suffering are repeated through continuing apocalyptic myth-like ending. 


\section{Charles Djungu-Simba's political discourse presentation and argument}

Each novella in Les Terrassiers de Bukauu: Nouvelles presents characters who, in spite of their dreams, ambitions and opportunities made possible by their educated status, all fall into a vicious cycle that perpetuates starvation, poverty, illiteracy, war, violence, women's victimization, and death as daily realities. The reader could think of those who are not depicted - still present in the background of narratives - in their wealthy situation as leading a better life. However, chaos engulfs everything because true prosperity is impossible to achieve when a significant section of the population experiences death on a daily basis and lives in an environment where a total absence of political organization or leadership has led to an abundance of bandits of many kinds, including corrupt political and religious leaders, who operate against the people.

The first novella, "Et le ciel s'assombrit", ["And the Sky Became Dark"] constitutes the only contribution to the book by a female author's. Clearly, this deliberate choice plays a very important role. As a metaphor, it fills a mother function giving life to different kinds of children as illustrated in all other novellas. The metaphor repeats an African proverb comparing a mother's womb to a field where different species of crops grow whereas weeds fill most space leaving no chance for good crops to grow to their full size. In fact, Astrid Mujinga, the writer of the first novella depicts family life in a chaotic environment. Thus, from the beginning of the book, the female and maternal references describe difficult existential conditions and the possibility of salvation and welfare through new generations. In fact, family situations are described in the first lines: "Waku relut pour la enième fois la lettre..." (Waku reread the letter for an unknown time) (p.3i). Reading the letter several times shows the difficulty she has communicating in real time. In addition, the letter comes from the neighboring Rwanda, and brings bad news about illnesses suffered by fragile members of the family. This news depicts a situation in which death seems inevitable, but at the same time life can be saved with the right decisions and adequate means. It is a binary system, a dual presence of life and death, success and failure within a continuum, a continuous duality that Djungu-Simba's collection segments in the selected novellas, depicting chaos and failure, on the one hand, and hopefulness on the other. Another illustration can be found in the novella "Les Apparences Trompeuses", ["Deceiving Appearances"]. Although Doctor Katunga and an unnamed nurse, under the authority of occupant forces, are both obliged to work at the hospital, they have opposite attitudes. Doctor Katunga forgets about his own suffering. He wants to save lives by offering his service. The nurse refuses to give hospital serums. He wants money (pp. 76-77).

The maternal imagery or metaphor leaves space to the community role in the raising of a new generation or better in the re-construction of the social tissue. There is a need of much strength and power in order to "Terrasser" (p. 9) or to plow and dig deep channels, i.e., to construct, build or re-build Bukavu. For the re-construction of the city, much work is needed in order to obtain effective results. The title of the first novella "Et le ciel s'assombrit", ["And the Sky Became Dark"] predicts the need for hard work, genius and technology in order to achieve rebirth from the dreadful situation the narrator depicts: a 
dirty, muddy ground awash with rainwater and an impossible circulation of goats and people searching for shelter. It is from that unfortunate environment that Bukavu must be born anew through a "mythic process" that leads back to its original shape, beauty and closeness with nature that made of it a rich place that gods loved. This journey back to the "illo tempore", the ["once upon a time"] traces back to the mountain from which God gave cows to Bukavu people. In the post-scriptum (p. 153), Rubango explains the local oral narratives turning around cow myths that illustrate the original wealth, the beauty of Bukavu and the surrounding area, as a gift from the creators still celebrated in local rituals and oral narratives. In popular myths, Bukavu is practically an altar where creation, reconciliation and meeting rituals celebrate deities and their powers. It is also portrayed as a safe space that reproduces life.

In the mythic continuum, ritual celebrations, especially purification rituals, request harmony from the community as a sine qua non condition for progress. This step does not seem simple given the general results of war, violence, misunderstanding, threats and ethnic divisions. Whereas neighbors and friends can be asked to do their best and pay back debts (the case of Tchim's), share food with visitors as in the case of Bonané and his wife, it is still very difficult to find agreement with some inhabitants of the same area identified, or suspected of collaborating with the invaders, killers and those whose presence is seen in terms of the dirt (p. 37). The first novella's title, "Et le ciel s'assombrit", ["And the Sky Became Dark"], stands as a forecast of terror and violence as the sky predicts floods. On identities either related to language, to customs and especially to any support given to the invaders, the community is very much divided, as the enemy is differently perceived. Even children have their own ideas and evaluation criteria and do not miss an opportunity to side with their parents, and at least to give a contour to their own understanding of identity, adversity, enmity and vengeance - or vendetta - for blood's sake. Children fighting in school justify their identity in their own way and, by the same token, bullying the students whose parents, rightly or wrongly, are thought to represent the common enemy that has caused their families' suffering. These children feel the need to take part in the conflict even though nobody has ever advised them to do so (pp. 3839).

This first novella generates the main repeated features that characterize Charles Djungu-Simba's discourse. It deviates from previous narratives related either to the independence question, or to Lumumba's double-edgedpolitical discourse, or to speech and freedom of expression as mentioned above. It recuperates historical and emotional testimonies that are organized in such a way as to strongly cohere and move smoothly from one segment to another, captivating the audience while leading it to its own complementary message production through a metanarrative of responsibility. In addition, when writers' minds produce narratives that mix reality and fiction, using their own social indicators, they state logical problems and suggest coherent answers, often freely expressing their emotions. Floods understood literally and figuratively as presented in this first novella shed light on human violence and build up the main chaotic imagery carried on all pages and in all novellas as the skies are dark predicting more rain, and the ground is already slippery and full of mud. 
The second novella by Sim Kilosho Kambale, "Les malheurs de Joséphine", ["Josephine's Misfortunes"] stresses how the population's misfortune is very much linked to foreigners present in Bukavu and elsewhere in the country. It once again pinpoints the poverty, previously depicted through Tchim's debt, and the general environment suffering from rainwater and the threat of flood, as the skies get darker and darker. However, Djungu-Simba's discourse, developed in the succession of selected novellas, offers evidence on how difficult it is to develop effective strategies and workable plans in order to solve social issues if important sacrifices are not agreed upon.

Josephine's misfortune caused by her frivolity and use of morally mean strategies supports the warning to be as careful as possible. Similarly, many Bukavu girls often try to find solutions through selling sex with different people, and especially with United Nations agents. The same girls are often taken as hostages and used as sex slaves.

Josephine, a pastor's daughter, demonstrates how prostitution has become a means of survival for many girls. However, when she attempts to capitalize on her illegal and immoral financial resources gained through prostitution, she moves to a legal business selling precious stones that were unknowingly fraudulently bought from Walikale village people. Thus, she falls victim to crooks (pp. 54-58), who lure her and run away with her money leaving her with valueless pebbles. Nicknamed by her community, "J'ose la Belle" or "Daring the Beautiful", her name change indicates her capacity to try any means possible, however unwise it may be, to achieve her ends, including a second failed attempt that leads to HIV-AIDS resulting from unprotected sex. On her way back home, as she is crying and reflecting on the losses accumulated through her life of prostitution, very dark and heavy skies gather above Lake Kivu, Nyungwe and Cyagungu cities. Heavy rains start pouring, thus making a quick link to the general idea of flood, apocalypse and chaos as documented by Leonard and McClure (2004).

Josephine's traumatic experiences prolong the imagery that characterizes the discourse elaborated in the first novella. Dark skies, heavy rains and floods are a continuation of a muddy city, slippery spaces, disorder and chaos. Prostitution - female, male or political - reinforces personal suffering and leaves the community without hope as it prevents personal, communal, or administrative rebirth. This novella also points out that little can be expected from foreign forces present in Bukavu and in the country. The United Nations Forces are shown in their weaknesses participating in prostitution and leading amoral lives by using their high salaries to objectify people, particularly women, who they are supposed to protect against evil forces (p. 55). The presence of United Nations Forces is unlikely to lead to a general renewal. The soldiers have forgotten their primary mission to bring peace and harmony to the people and to promote community life in spite of the diversity of the population. On the contrary, they are shown as victims of the same chaotic influences. In addition, the novella clearly depicts the impotence of the Church through the character of Josephine's father, the pastor. His own daughter falls into prostitution and finally suffers from HIV-AIDS, a disease against which medical institutions in the Democratic Republic of the Congo are inadequately equipped... 
Political leaders, when presented at all in the novellas, are careless and useless (pp. 83-IOI). Ethnic influences and considerations have invaded the once believed sacred institutions - politics and religion - as both partake in the general apocalyptic environment, and eventually disintegrate and collapse as victims under the Armageddon (pp. I05I07). In fact, any re-organization or attempt at harmony that is not well monitored or does not have highly qualified moral standards is doomed to failure from its beginning. The understanding of a general conversion includes the acknowledgement of personal weaknesses and individual responsibility towards some situations before pointing fingers to others, and the capacity to offer sacrifices that can satisfy the gods.

Conversion also implies harmonization with everybody, including neighbors, friends and enemies, neighboring countries. The process remains inclusive rather than exclusive so that "adaptation, alteration, modification, reconstruction, redesign, redevelopment, rehabilitation" lead to true change through rites of passage. Arnold van Gennep (I960) gives an illustration of how the individual participates in community life and growth in partaking in different rites and rituals. Rites fundamentally teach the individual to rid him or herself of egotism, and consider the individual as part of the community energy and life. They also teach resistance in all difficult conditions whereas rituals stand for the moments solemn promises are made demonstrating a deep respect for community interests and values.

The third novella starts from this point, stressing an archetypal transformational imagery that is continued in the title "Apparences Trompeuses", ["Deceiving Appearances"], and in the first sentence of the narrative "Mais ces deux villes s'interpénètrent", or "these two cities penetrate each other" (p. 7I). The explanation of the word "penetration" reduces to zero the distance separating these two countries, namely Rwanda and the Democratic Republic of the Congo. They are very close and the same people may inhabit both borders and may, in particular, share the same culture or let us say in this case precisely have the same facies (see the above example of Jonathan bullying classmate Anastase Sengiyunva simply because of his facies and his belonging to a given ethnic group). In addition, the reader easily comprehends that in this neighborhood, there is a kind of brotherhood based on mutual assistance and security principles.

Moreover, the closeness of both lands penetrating each other refers to a biblical archetypal image of creation in the book of Genesis. This book gives two different accounts of woman's creation. The first account considers a spontaneous creation of both male and female whereas the second gives a scene where the female is created from man's rib in which God insufflates a living force. In both cases, both creatures are very close. There is also the idea of creation ex nihilo that myths, especially in narratives similar to biblical creation texts, use to show the spontaneity of creation. Whether the reader looks at the penetration image as the male and female coming from the same body or from other mythological techniques leading to procreation capacities as described by Leonard and McClure (2004), both lands change in the imagery of creation or procreation that supposes closeness and love. All the same, in the scenario presented, there is no chance for love and understanding; war and violence have torn people apart, and rapes 
have accompanied violence, portraying hatred, disdain and the commoditization of human beings. The discourse - and metanarratives - insists on the fact that, in the absence of human rights, universal societal conventions, and above all love, closeness would not prevent people from using each other as means rather than ends. There is an absence, then, of that supposes detachment from personal egotistic benefits for the sake of the Res Publica, the country.

To deepen the idea of closeness versus possible violence in the absence of any moral rule and community leadership, the writer of the novella "Les Apparences Trompeuses", ["Deceiving Appearances"] reveals strategies that revolve around how two very close countries attack each other and lead to a general lack of confidence (p.73). In addition, the total absence of political authority testifies how uninterested politicians are in their constituencies and build up their power for power's sake. The politicians' unidentified and unclassified modus operandi opposes ethnic groups and countries often over futile aims. In contrast to this, Doctor $\mathrm{Ka}-\mathrm{a}$ character in this novella "Apparences Trompeuses", ["Deceiving Appearances"] -, decides to help people who find themselves in unacceptable situations, in spite of his own family issues and fears. Whereas nurses used the war as an opportunity to force different fees on people coming to the hospital for health care (p. 77), Dr. Ka chose to look at the hospital as an opportunity to assist suffering people. He exemplifies a new profile of politician.

Perceived within the chaos or the total confusion, the behavior of these nurses is symptomatic of the general chaos visibly manifest in the novella through the total absence of charity and understanding in the community. The discourse developed in the novella, "Apparences Trompeuses", ["Deceiving Appearances"], once again points at the ubiquitous nature of evil. The scene depicting Noe, the nurse (p. 78) shouting at a patient's husband in order to get a payment for the blood-testing drop she gave the doctor illustrates the general presence of corruption. Thus, whereas Doctor Ka stands for a local proposal that can launch local community initiatives and charity, the nurse stands for human failure that perpetuates violence, hatred, and dehumanization. Doctor Ka's presence in the hospital attracts attention and respect: "Docteur Anakuya. Here is the Doctor! (p. 78)". He can bring about changes in some behavior even though he cannot be understood at once. Even the most feared mythic militias respect his work because only human life - that Dr. Ka works for - makes possible a project of whatever kind.

It is with the idea of accepted suffering, servicing, and ownership, on the one hand, and inherent violence and abuses, on the other hand, that the discourse organizer, i.e., Djungu-Simba, bridges this step to the next one. The fourth novella "De la résistance à la liberation", ["From Resistance to Liberation"] continues the theme related to community service in a sector other than health. It highlights politics and public opinion and shows how people do not blindly accept their suffering. Many expect salvation to come from above, i.e. from God, as their desperation cannot find any relief from human agency political leaders, ethnic group partners and neighbors. However, it is out of this confusion that a group of young people develops plans to distribute tracts with the intention of raising spirits, resisting a corrupt power, denouncing dictatorship and bringing about 
change from the deliquescent and dehumanizing power. The small group of young people - including Passy, Harry, Nando, and Timon - has decided to do something in order to change their situation. The eastern Congo was for many years under the occupation of its neighbors, mainly Rwandans. Officially, a national government has taken the top control of the country, but the suffering is still present. The young people have decided to distribute tracts in order to sensitize as many people as possible in a bid to attract their leaders' attention. Unfortunately, one of them, Timon, reveals the secret, betrays his friends, and they are caught. This is another example showing that the fruit is rotten on the inside, i.e. Bukavu people or largely speaking Congolese have to take care of their many issues in addition to those that neighbors may be accused of.

Even though this is a very meaningful signal that youth - often referred to as the new generation - get involved in the destiny of their populations, the writer uses techniques that foreground the lack of experience and/or wisdom of youth. The idea of distributing tracts - calling for resistance - in order to raise public awareness is wonderful, but somehow weakened when the young people are betrayed and finally imprisoned. Otherwise, the young people's failure can still be viewed as a call to communal work and collective responsibility, without any exclusion of older generations.

The above section of the discourse also repeats a Roman idiom, considered as universal truth today: "Homo homini Lupus", [man is a wolf for other people]. Politicians, for instance, in Bukavu and certainly elsewhere in the Congo, do not hesitate to get rid of "dangerous" opponents. However, as possible ways out, the text identifies networks that never leave alone those people exposed to dictatorship or prison suffering. After a denunciation of the abusive use of poison for killing incarcerated people, Mado, the woman in charge of bringing food to the jail brings solace to the young people, and promises to spare their lives (pp. 89-9o). They are able to inform their families, local and international human rights associations of their situation thanks to Patty who is freed as he is not found to be involved in writing tracts (p. 90). In fact, African governments - for various reasons but mainly for international economic assistance, submitted to conditions - are very much concerned with their outer rather than inner image and avoid as far as possible their dictatorial practices being aired around the world. It is in fact thanks to a communication strategy that the imprisoned group finally finds freedom. Needless to say the presence of Mado pinpoints that future perspectives cannot be possible without the contribution of women.

"De la résistance à la libération", ["From Resistance to Liberation"], still duplicates, amplifies and continues the theme of general chaos and confusion showing the capacity of evil to contaminate the social environment. This is taken a step further with the addition of a new discourse segment, the contribution of security and political institutions to the general anarchy and violence in society. Many citizens are incarcerated and kept away from any possible outside connection, or killed, whereas only a minority are saved, thanks to the above described communication strategies and networks.

This part also focuses on public speeches and their impact on the population. The President, clearly identified as Mzee Kabila, i.e., Laurent Désiré Kabila, talks about the 
arrested people and compares them with the intellectuals who ruined the country under the first dictatorship, i.e., under the rule of President Mobutu. In such circumstances, the reference to the past would normally attract the entire population against the public enemy. However, this works only when the people identify the enemy as the reason for their suffering, which is not presently the case. It is through that disorder - people suffering from their leaders' incapacity and incompetence - that finally the "heroes" reach their community where everybody is waiting for them (pp. I00-I02). The young people stand for potential hope and the capacity to bring about expected changes as a logical outcome of an apocalyptic myth.

To continue with the idea of general degradation, the following novella, "Les Coulisses d'une ville oubliée", ["The Corridors of a Forgotten City"] centres on the architectural presentation of Bukavu. This depiction includes not only the general architecture of the area, but also the way in which different anarchic mushroom-like constructions raised everywhere denote how superficial many people are, and how some, in spite of the general poverty, wish to create the impression of wealth. The illusion of getting easily into leadership positions either as politicians or social organizers leads many to act in incoherent ways without taking into account the environment and responsibility for future generations. Such attitudes only duplicate the general chaos, and reinforce the general suffering.

In an illustration of the writing imagination for a region full of mountains close to and all around Lake Kivu that offers the beautiful scenery of water and a panoramic view, the writer places all manner of constructions as a power-show of the new wealth. These rich people often take by force the properties of the poor, but can be punished by nature that turns everything on its head. Chaos ensues when an earthquake turns everything upside down, unconventional and poorly constructed houses are reduced to piles of debris. However, the owners, who ignored the laws are quick to obtain new authorization papers, through corrupt means, to rebuild in the same exiguous, dangerous and inadmissible locations. The earthquake caught people by surprise as they worshipped in Bukavu cathedral on a Sunday. Surprise, fear and bewilderment send people running in different directions, some forgetting their children and personal valuables. Church and religion cannot protect the population from this chaos when the entire community seemingly makes bad judgments and does not differentiate between right and wrong.

The upside down vision that this earthquake reveals (pp. 105-107) also extends to personal justice. Since the general administration does not offer a safe, protective environment against thieves and other bandits, people take matters into their own hands and arrest the thieves. In the anarchy, the population punish anyone caught stealing or breaking into houses, and select punishments reserved for criminals that are often disproportionate to the crimes. Meanwhile, some international experts or United Nations agents lead openly amoral lives and are not punished at all for their immorality or failure to assistance to the most fragile population in need.

Darius Kitoka, the author of "Les coulisses d'une Ville Oubliée", ["The corridors of a forgotten city"], takes a closer look at the daily lives of people and depicts their new habits. 
Any social event provides an opportunity to increase friendships and to bring the community together. However, events such as marriages, social invitations and government services are all opportunities for different kinds of corruption. Thus, invitations to feasts and celebrations are seen by "poor" people as a means to obtain money and satisfy their own needs even though they are all facing starvation and financial challenges. In addition, the police show little concern for protecting people. They see these people as a source of income through extortion. Finally, all these contribute to the confirmation of general chaos.

Djungu-Simba adds his ideas in the section entitled "Post-Scriptum", which can be considered the conclusion of all the other narratives depicting the general chaos. However, this part deals exclusively with the presence of United Nations Forces in the country and their participation in the general chaos and increase in turmoil. An invisible vicious circle condemns all their actions to move back to the same starting point of chaos; these international forces cannot obviously bring about rapid change or progress. The writer calls on the United Nations Forces to help restore dignity and pride since, unfortunately, many United Nations agents are seen rather acting in their own interests in terms of prostitutes and through their general carelessness aggravating the general climate of insecurity. The example of Cyprian and Sengera is very eloquent. The gentleman offers his wife to a United Nations agent for money so that she can bring him money to solve their family issues. Unfortunately, responding to the general pattern, this idea leads to the same chaos as his wife falls in love with the United Nations agent and finally forsakes her marriage and leaves for Monrovia with the same agent. The reader rightly raises the question of whether that is the end of everything. That is exactly how the apocalyptic mythic pattern works in order to lead to a rebirth. It is therefore time for another "revolution" or cycle to start and bring new life to Bukavu in particular and the Congo in general with the help of the reader.

\section{Conclusion}

The novellas grouped in this book certainly do not present the same political discourse argumentation, or the same sequential presentation of actions that lead to the general described disorder. Nevertheless, they all respond to the same pattern depicting a general turbulence, chaos and an apocalyptic ending. If those who brought war and destruction came from close neighbor Rwanda, it is obvious that there is participation of elements inside Bukavu who collaborated with the general extension of the chaos. The general authority deliquescence touches all social sectors. At the same time, locals pretended to support the war to liberate their country, but quickly changed in tolerating the perpetrators.

In parallel, yet in the background, the book develops a family imagery essentially revolving around parents, children, close family members and friends. As the suffering and chaos that impinge on Bukavu social life goes on, we see school children meting out their own kind of justice by beating their classmate. It is a boy from the ethnic group suspected of collaboration with the invaders, killers and rapists. These children's reac- 
tion may be judged as lacking discernment, doubtlessly because of their young age. In contrast, the "Baghdadi" boys - as they are called - take the decision to distribute tracts and denounce the dictatorship, in spite of what could be called a lack of age wisdom. This is also dealt with as a literary device inviting them to community actions. The reader is slowly led to understand that young people are at the center of the future. Finally, the main theme revolves around a general chaos, on the one hand, hope for a better future, on the other hand, but only if everybody takes seriously the challenges and accepts the difficult therapy: changing oneself, forgiveness, and above all a new kind of leadership.

In combination, these novellas offer a comprehensive historical background on $\mathrm{Bu}$ kavu and the country. All authors use terms such as turbulence, apocalypse and myth, which provide a new language for considering the tribulations in the Congo, and utilize literary devices that largely pave the way for a clear reading and analysis of the novellas. All writers provide theoretical and scholarly data that permit the de-construction of narratives in order to understand the breadth of the chaos emanating from flood, earthquake, volcano flows, debris, and human violence - the final end of a cycle or system - and the rejuvenating energy that emanates from young generations and community conversion leading to renewal.

The readers in general and the Bukavu population in particular are familiar with biblical texts and imagery. They can easily remember that the biblical books of Genesis and Apocalypse are both constructed around chaos and logically complete each other. Whereas Genesis shows chaos observed prior to creation, the Apocalypse shows how a general chaos due to a lack of harmony leads to the doomsday, and is but a necessary step for re-creation. Thus, the novellas mentioning mud, thunders, flooding channels also offer imagery and metaphors of how everything contributes to utter chaos, a state of complete confusion, and a night-like apocalypse.

It is within that confusion that "les héros de la résistance congolaise incarnée dans le jeune trio de Bagdad: Passy, Harry et Nando; [Congolese resistance heroes embodied in the young Bagdad trio: Passy, Harry and Nando, heroes of the Congolese resistance"] as mentioned in "De la Resistance à la Liberation", ["From Resistance to Liberation"] start their action. These young people stand like an artifact that the community artist has carved. They are Bukavu's positive potential. Whatever happens, the motherland will count on its youth to rebuild its most essential elements. This image repeats the pattern already seen in the first novella, where family life is presented as the most important human dynamic, the very fabric that can eventually bring about a new kind of people, strong enough to rebuild Bukavu from its ashes, based on strong ethical norms. The writer incidentally uses the Greek Mythology image of the phoenix to clearly suggest a rebirth at the example of the mythical bird that resurrects from its ashes. This image has turned in a worldwide metaphor that shows people's capacity to rebuild life, resistance, and humanity from the most unthinkable situations or crises.

The selection and order of the segments comprising this collection of novellas offer what should be perceived as Djungu-Simba's political discourse, based on literary communication strategies. As they come from stories shared with families or with close 
friends, they may be seen as socio-political indicators shared with readers through semiotic levels. First, the people of Bukavu are completely forsaken in the plight of facing the dangerous unknown. They do not have leaders; on the contrary, every inside or outside adventurer can impose on them any kind of suffering. Second, the novella collection concurs that when taken in the light of the Roman idea of thinking of people in terms of bread and games ["panem et circenses"], Bukavu is almost dead. It does not have the chance to feed its population properly nor allow them to enjoy life through various kinds of distractions and hobbies. All the novellas vividly show the total suffering that people face from all sides without any hope of a rapid or timely change. Third, to communicate the omnipresence of violence, suffering and death, the novellas stand for segments of an apocalyptic myth that shows a vicious circle inexorably leading to death. Fourth, a new cycle is likely to arise from the general chaos if each person makes a commitment to start a new way of life through sacrifice, harmony, and acceptance of a new kind of leadership in a new environment. Under these conditions, Bukavu can enjoy its original miracles of beauty and natural wealth while its citizens benefit from the commonwealth. Fifth, the semiotic dynamic still allows the development of Bukavu to freely go through other metanarratives, achieving greater responsibility at all levels. This new type of discourse does not directly attack leaders and politicians but presents them with images and concerns that necessarily demand their reaction. Sixth, through his new socio-political, collected, edited, and sequentially organized narratives, Djungu-Simba finally succeeds, though using mostly other people's narratives, in "mythbreaking" the general atmosphere turning around chaos. He becomes more than a griot using material inherited from a long past; he becomes a "mythmaker", permitting audiences and readers to dream of a better Bukavu, a better world, through a new cycle that involves personal, community, and global respect and responsibilities. In the Post-Scriptum, Dujungu-Simba moves through the character of Cyprien who sacrifices his wife and family for money to demonstrate how human dignity and justice can be corrupt, but can still be recuperated through personal and community will, and hard work.

\section{References}

Abrams, M.H. \& Harphan, G.G. (1999). A glossary of literary terms. (7th ed.) Cornell University: Heinde \& Heinde, Thomson Learning.

Biebuyck, D.P. \& Kahombo C.M. (Eds. \& Trans.), (1989). The Mwindo epic from the Banyanga (Congo Republic). California: University of California Press.

Blair, D.S. (1976). African literature in French: A history of creative writing in French from West and Equatorial Africa. Cambridge: Cambridge University Press.

Booth, W.C. (1967). Distance and point of view: An essay in classification. In P. Stevick, (Ed.) Theory of the novel (pp. 88-97). New York, NY: Free Press, a Division of the Macmillan Publishing. (1983). The Rhetoric of Fiction (2nd ed.). Chicago, IL: University of Chicago Press.

Buckley-Zistel, S. (2008). Between past and future. An assessment of the transition from conflict to peace in postgenocide Rwanda. Germany: Deutsche Stiftung Friedensforschung.

Brown, C. (2012). Rape as a Weapon of War in the Democratic Republic of the Congo. Torture. Volume 22.

Campbell, J. (1972). The hero with a thousand faces. Princeton, NJ: Princeton University Press. 
(I990). Transformation of myth through time. New York, NY: Harper \& Row.

Conrad, J. (1989). Heart of darkness. London: Penguin books. (2006). Heart of Darkness. London: Collectors Library, CRW Publishing Limited.

Cook, M. \& Henderson, S.E. (1969). The militant black writer in Africa and the United States. Madison: the University of Wisconsin Press.

Cuddon, J.A. (2013). Dictionary of literary terms and literary theory (5th ed.). M.A.R. Habib et al. (Eds.). New Jersey: Wiley-Blackwell.

Dathorne, O.R. (1976). African literature in the twentieth century. Minnesota: The University of Minnesota Press.

De Witte, L. (2002). The assassination of Lumumba. (A. Wright \& R. Fenby, Trans) United Kingdom: Verso.

Dibwe Dia Mwembu, D. et al. (2010). Lubumbashi 1910-2010: Mémoire d'une ville industrielle / Ukumbusho wa mukini wa komponi. Préface de V-Y Mudimbe. Paris : l'Harmattan.

Djungu-Simba K.C. (2009) Les terrassiers de Bukavu: Nouvelles. Paris: l'Harmattan, Ecrire l'Afrique.

Doyle, A.C. (I909). The Crime of the Congo. London: Hutchinson \& Co.

Eliade, M. (I96I). Images and symbols: Studies in religious symbolism. New York, NY: Sheed and Ward. (I963). Myth and reality (W. R. Trask, Trans). New York: Harper \& Row.

(1978). A history of religious idea: From the Stone Age to the Eleusinian mysteries. (Vol. I). Chicago, IL: the University of Chicago Press.

(1985). Symbolism, the sacred, and the arts. D. Apostolos-Cappadona (Ed.). New York, NY: Crossroad Publishing.

(2004). Shamanism: Archaic techniques of ecstasy. Princeton, NJ: Princeton University Press.

(2005). The myth of the eternal return: Cosmos and history. Princeton, NJ: Princeton University Press.

Finnegan, R. (1970). Oral literature in Africa. Oxford: The Clarendon Press.

Forster, E.M. (1947). Aspects of the novel. London: Harcourt.

Fossion, A. (1980). Lire les Ecritures : Théorie et pratique de la lecture structurale. Bruxelles: Lumen Vitae.

Freeman, N. (1967). Forms of the plot. (p. 198). P. Stevick (Ed.). The theory of the novel. New York, NY; Free Press, Division of the Macmillan Publishing Co.

Gennep, A. V. (1960). The rites of passage. Chicago, IL: The University of Chicago Press.

Gondola, C.D. (2002) The history of Congo: The Grennwood histories of modern nations. Wesport: Greenwood Press.

Greimas, A.J. (1984). Structural semiotics: An attempt at a method. Nebraska: University of Nebraska Press.

Guattari, F. (I995). Chaosmosis, an ethico-aesthetic paradigm. (P. Bains \& J. Pefanis, Trans.). Indianapolis: Indiana University Press.

Hale, T.A. (I997). From the griot of roots to the roots of griot: A new look at the origins of a controversial African term for bard. Oral Tradition, I2 (2), pp. 249-279.

Harvey. W.J. (1967). The Human Context (p. 232). P. Stevick (Ed.). The theory of the novel. New York, NY; Free Press, Division of the Macmillan Publishing Co.

Henderson, J.L. \& Maud O. (1963). The wisdom of the serpent: The myths of death, rebirth and resurrection. New York, NY: George Braziller.

Hochschild, A. (1998). King Leopold's ghost. USA: Mariner Books.

Kaputu, F.U. (2010). Beyond the east and the west: An African view of Japanese aesthetics. In I. Shimegi (Ed.), Questioning Oriental Aesthetics and Thinking Conflicting Visions of "Asia" under the Colonial Empire. the 38th International Research Symposium, Kyoto, Japan: International Research Center for Japanese Studies.

(2010). Global shamanism in context: Itako (from Osorezan, Aomori, Japan) and Mikishi (Lake Mweru, Katanga, Democratic Republic of Congo). Asian Cultural Studies, International Christian University, Publications 3-A, p. 36. 
(2010). The deadly pandemic, quarter a century after: The Katanga Province (D.R. Congo), and the Northwestern Province (Zambia) Women in a World of HIV-AIDS. The Journal of Social Science, 69.

Leonard, M., \& McClure, M. (2004). Myth and knowing: An introduction to world mythology. New York, NY: McGraw-Hill Higher Education.

MacGaffey, W. (I983). Modern Kongo prophets: Religion in a plural society. Bloomington, IN: Indiana University Press.

Murphy, D. (200I). Sembene: Imagining alternatives in film and fiction. Oxford: James Currey Ltd.

Ndaywel e Nziem, I. (1998). Histoire générale du Congo: de l'héritage ancien à la République Démocratique. Préface de Théophile Obenga, Postface de Pierre Salmon. Paris: Commissariat Général aux Relations Internationales, Editions Duculot Afrique, Agence de la Francophonie, De Boeck \& Larcier S.A.

Ngandu, P.N. (1984). Littératures africaines: de 1930 à nos jours. Paris: éditions Silex.

Nzbatsinda, A. (1997). Le griot dans le récit d'Ousmane Sembene: entre la rupture et la continuité d'une représentation de la parole africaine. The French Review. 70 (6), pp. 865-872.

Okpewho, I. (1992). African oral literature: Backgrounds, character, and continuity. Bloomington: Indiana University Press.

Prunier, G. (2009). Africa's world war: Congo, the Rwandan genocide, and the making of a continental castrophe. London: Oxford University Press.

Rahman, N. (2009). Apocalyptic Narrative Recalls The Human: Rawi Hage's De Niro's Game. University of Toronto Quarterly, Volume 78, issue 2, pp. 800-8r4.

Rancière, J. (2004). The politics of literature. Substance, I03, 33(I), pp. I0-24.

Rubango, N.Y. (1999). D'un discours colonial Congolais à l'autre. Congo-Meuse: l'oeil de l'autre. Colloques de Kinshasa et de Bruxelles. CGRI: Publication annuelle $\mathrm{n}^{\circ} 2$ et 3, pp. 607-637.

(1999). Patrice Lumumba at the crossroads of history and myth. A Congo Chronicle: Patrice Lumumba in Urban Art. By Bomumil Jewsiewiki with contributions from Dibwe dia Mwembu, Mary Nooter Roberts and Allen E. Roberts, Nyunda ya Rubango, Jean Omasombo Tshonda. New York: the Museum of African Art.

(2000). Patrice Lumumba en son temps: un modéré?. Patrice Lumumba en Dieu et Diable: un héros africain dans nos images. Etudes et documents réunis par Pierre Halen et János Riesz. Paris: l'Harmattan, pp. 295309.

(2009). Congo-Zaire (1990-2005): de l'«empire du silence à l'«empire de la mort. Discours de violences et de souffrances (1990-2005). In Isidore Ndaywel è Nziem et Elizabeth Mudimbe-Boyi (éds), Images, memoires et savoirs: une histoire en partage avec Bogumil Koss Jewsiewicki. Préface de Pierre Nora de l'Académie française. Paris: Editions Karthala, pp. 673-698.

Russel, B. (200I). Freedom and Orgnisation 1814-1914. New York: Routeledge, New Edition.

Scholes, R. (1978). Structuralism in literature: An introduction. New Haven: Yale University Press.

Sekoni, R. (1990). Narrative Pattern and Audience Experience. The Oral Performance in Africa. Edited by Isidore Okpewho. Ibadan: Spectrum Books Limited.

Walsh, R. (2007). The rhetoric of fictionality: Narrative theory and the idea of fiction. Ohio: The Ohio State University Press Columbus.

Waugh, P.N. (1992). Practicing Postmodernism. London: Edward Arnold.

Wellek, R. \& Warren, A. (I956). Theory of literature. New York, NY: Harcourt, Brace.

Yasui, H. (I982). Literature and film: The social aesthetics of distance. University of Wisconsin-Madison. 